腋窩キャッスルマン病を合併した原発性肺癌の一例

柿添学*1, 鈴木 浩介*2, 佐伯 典之*1

\begin{abstract}
要旨
症例は 67 歳男性. 検診にて胸部異常陰影を指摘され, 精査 CT で右肺 S4 結節と右腋窩結節を認めた. 肺結節は transbronchial lung biopsy (以下, TBLB)で腺癌, 腋窩結節は core needle biopsy (以下, CNB) で反応性リンパ節腫脹と診断された. FDG PET/CT では上記以外に病変を認めず，腋窩結節の maximum standardized uptake values（以下，SUVmax）は 4.1 と軽度高值であった．肺癌の腋窩リンパ節転移を完全に否定できなかったため，腋窩結節切除生検を施行した，術中迅速診 断で腋窩結節に明らかな悪性所見を認めなかったため，引き続き肺癌に対して定型手術を施行した．病理診断の結果，肺結 節は腺癌 pTlaN0M0 Stage IA，腋窩結節は hyaline vascular type のキャッスルマン病 (Castleman’s disease，以下 CD) と診 断された. CD は稀なリンパ増殖性疾患であるが, 本症例のように悪性腫瘍に合併することがある. その際は転移性りンパ節 腫脹と誤認される可能性もあり，正確な術前および術中診断が重要となる.
\end{abstract}

索引用語 : キャッスルマン病, 肺癌, 腋窩リンパ節

Castleman’s disease, lung cancer, axillary lymph node

\section{はじめに}

キャッスルマン病（Castleman's disease, 以下 CD) は 胸部や頸部に好発する稀なリンパ増殖性疾患である。今 回われわれは，肺癌の遠隔リンパ節転移との鑑別を要し た，肺癌同時合併性腋窩 CD の一例を経験したので報告 する。

\section{症例}

症 例 : 67 歳, 男性.

主 訴：健診異常.

既往歴：高血圧症, 高脂血症, 不整脈治療後 (アブレー ション)

アレルギー：なし.

喫煙歴：20 本/日 ×3-4 年（40 年前に禁煙）.

家族歴：特記事項なし.

現病歴：2014 年 9 月の健診で胸部レントゲン異常陰

${ }^{* 1}$ 大船中央病院呼吸器外科

*2昭和大学横浜市北部病院呼吸器センター

原稿受付 2015年 2 月 18 日

原稿採択 2015 年 3 月 12 日
影を指摘され当科受診. CT で右肺 S4 結節 $(15 \times 14 \mathrm{~mm})$ と右腋窩結節 $(26 \times 18 \mathrm{~mm})$ を認めた. FDG PET/CT を施行し, 病変の Maximum standardized uptake values (以下, SUVmax) はそれぞれ 4.6 と 4.1 であった. 肺結節 は transbronchial lung biopsy (以下，TBLB）で腺癌と診 断されたが, 腋窩結節は core needle biopsy (以下, CNB) で反応性リンパ節腫脹と診断された。肺癌の腋窩リンパ 節転移の可能性も否定できないことから，肺癌手術に先 行して腋窩結節切除生検の方針となった.

入院時現症：(身体所見) 身長 $175 \mathrm{~cm}$, 体重 $70 \mathrm{~kg}$, 体 温 $36.2^{\circ} \mathrm{C}$, 血圧 $114 / 74 \mathrm{mmHg}$ ，脈拍 $80 / \mathrm{min}$ 整， $\mathrm{SpO} 2$ 97\% (Room air)，右腋窩皮下に母指頭大の弾性軟な腫瘤 を触知，その他表在リンパ節触知せず．

（血液検查所見）WBC $6200 / \mu \mathrm{l}, \quad \mathrm{Hb} 13.6 \mathrm{~g} / \mathrm{dl}$ ，Plt 24.7 $\times 10^{5} / \mu \mathrm{l}$, LDH $97 \mathrm{U} / 1 \downarrow$, CRP $0.03 \mathrm{mg} / \mathrm{dl}$, 血糖 $93 \mathrm{mg} /$ $\mathrm{dl}, \mathrm{HbAlc}$ (NGSP) $5.5 \%$, CEA1.8 ng/ml $(\leq 5.0)$, CYFRA21 $1.5 \mathrm{ng} / \mathrm{ml}(\leq 3.5)$, SLX 抗原 $29 \mathrm{U} / \mathrm{ml}(\leq 38)$, ProGRP $43.5 \mathrm{pg} / \mathrm{ml}(<81)$.

(画像所見)

胸部単純 $\mathbf{X}$ 線写真（Fig. 1）：右中肺野外側に $17 \mathrm{~mm}$ 大の結節影を認めた. 
胸部造影 CT（Fig. 2)：(A) 右肺中葉 S4 に spicula を伴う $15 \times 14 \mathrm{~mm}$ の円形結節影を認めた. (B) 右腋窩に $26 \times 18 \mathrm{~mm}$ の造影効果を伴う類円形の結節影を認めた.

FDG PET/CT : 右肺 S4 結節および右腋窩結節にお ける SUVmax はそれぞれ 4.6 と 4.1 であった.

以上より術前診断 cTlaN0M0 Stage IA の肺腺癌およ び起源不明の右腋窩結節に対して, 肺癌手術に先行して 腋窩結節切除生検の方針となった。

手術所見 : 全身麻酔下に右腋窩結節切除生検を施行し た. 類円形の弾性軟な腫瘤で周囲との境界は比較的明瞭

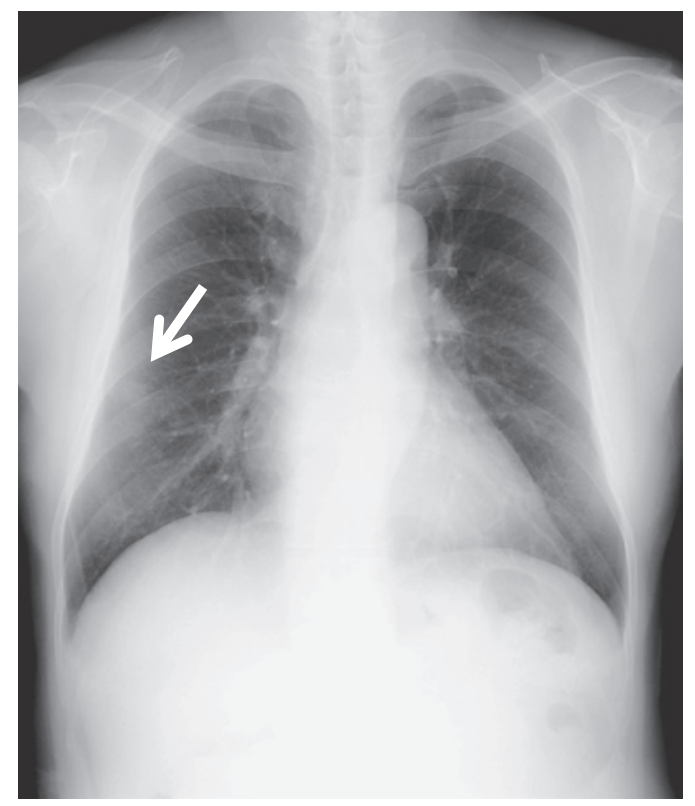

Fig. 1 A chest radiograph showed a 17-mm nodule in the right middle lung field.
であった，術中迅速病理診断の結果，悪性所見は認めな かったため，引き続きVideo-assisted thoracic surgery （VATS）にて右中葉切除術＋肺門リンパ節郭清（ND1b） を施行した. 手術所見は, RM-S4, $2.0 \times 1.7 \mathrm{~cm}, \mathrm{PL} 0, \mathrm{D} 0$, E0, PLC(未検), PM0, sTlaN0M0, Stage IA, R0 と診 断した.

病理組織所見 (Fig. 3)：(A) 右腋窩結節は, 割面が黄 白色の充実性腫瘤であった. (B) 顕微鏡的所見では肧中 心の滤胞樹枝細胞の上皮様増生や小リンパ球が同心円状 に配列し構成されたマントル層が認められた。また滤胞 間組織にも小血管の増生が強く，血管内皮の反応性腫大 と硝子様化が目立った. 硝子血管型の CD と診断した. な お, 肺結節の病理診断は乳頭型腺癌で, 胸膜浸潤や脈管 侵襲は認めなかった（pTlaN0M0, pStage IA）。

術後経過：現在外来にて無治療経過観察中であるが, 術後 4 力月の時点で肺癌および $\mathrm{CD}$ ともに再発は認めて いない.

\section{考察}

CD は 1956 年に Benjamin Castleman が初めて報告し た稀なリンパ増殖性疾患である ${ }^{11}$. 若年成人に多く性差は ないとされているが, 発生率が非常に少なく正確な統計 はない.インターロイキン 6 (IL-6) の過剩発現が発生に 関与しているとされ ${ }^{2.3)}$, 病理組織学的には hyaline vascular type（以下 HV 型）と plasma cell type（以下 PC 型)に分類される ${ }^{4)}$. 大部分を占める HV 型は無症候性の 限局したリンパ節腫脹で発見されることが多いが， PC 型は発熱，体重減少などの全身症状を呈する。なお mul-
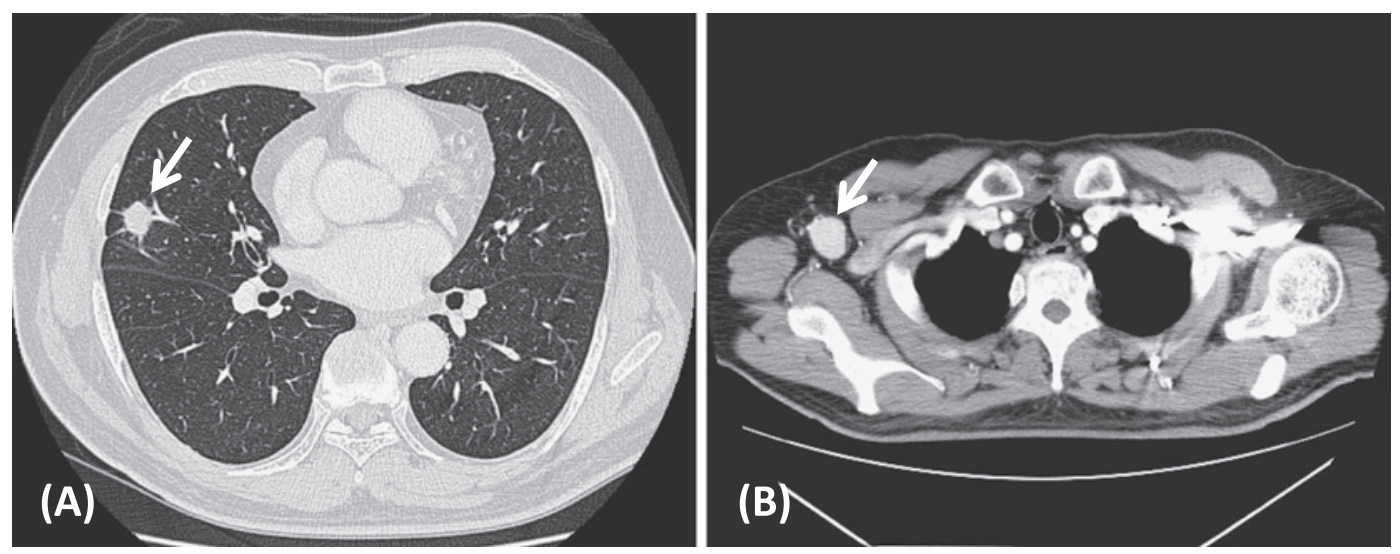

Fig. 2 Chest CT showed a 15-mm, spiculated nodule in the superior segment of the right middle lobe (A) and a 26-mm nodule with contrast enhancement at the right axilla (B). 


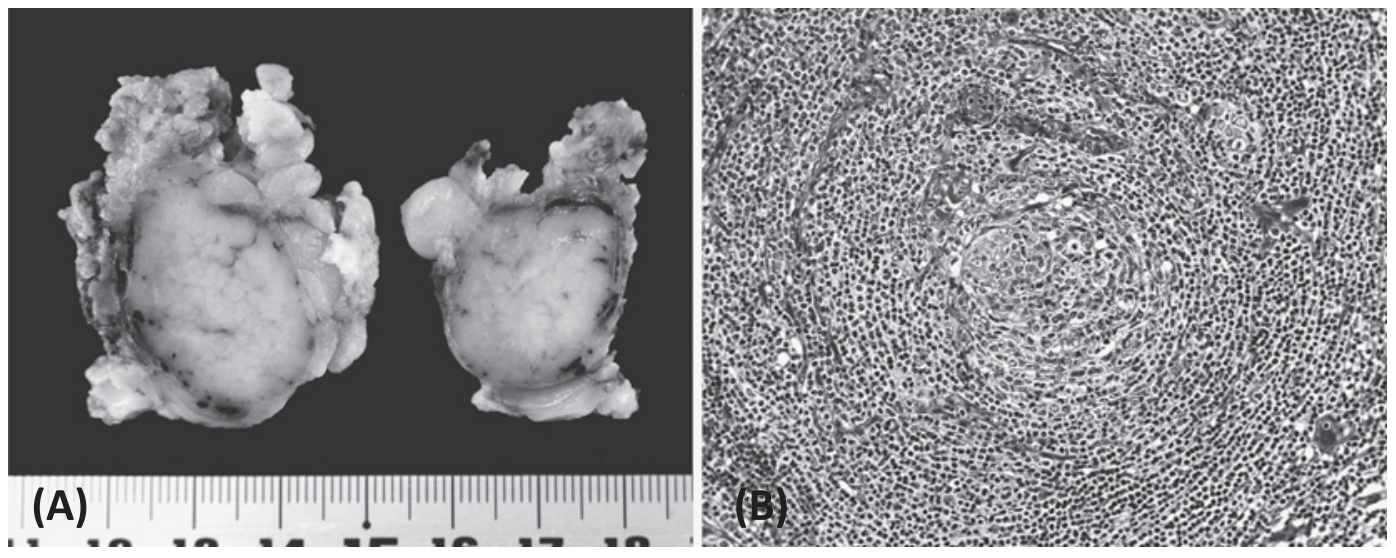

Fig. 3 The resected specimen of the axillary nodule revealed hyaline-vascular type Castleman's disease. (A) The cut surface of the solid nodule was $28 \times 20 \mathrm{~mm}$ in diameter and yellowish-white. (B) The histological findings showed that the follicle was surrounded by a broad mantle zone composed of concentric rings of small lymphocytes. HE stain.

Table 1 A summary of domestic case reports of primary lung cancer complicated with Castleman's disease

\begin{tabular}{|c|c|c|c|c|c|c|c|c|c|}
\hline Author & $\begin{array}{l}\text { Age/ } \\
\text { Sex }\end{array}$ & $\begin{array}{l}\text { Symptom } \\
\text { of CD }\end{array}$ & $\begin{array}{l}\text { UCD/ } \\
\mathrm{MCD}\end{array}$ & Location & $\begin{array}{l}\text { Tumor } \\
\text { size }\end{array}$ & $\begin{array}{l}\text { Diagnosis } \\
\text { based on }\end{array}$ & $\begin{array}{l}\text { Pathology } \\
\text { of CD }\end{array}$ & Lung cancer & $\begin{array}{c}\text { Recurrence } \\
\text { of CD }\end{array}$ \\
\hline Nagao ${ }^{14)}$ & $37 / \mathrm{M}$ & $(-)$ & UCD & chest wall & $3 \mathrm{~cm}$ & resection & $\mathrm{HV}$ & $\begin{array}{l}\text { adenocarcinoma, } \\
\text { por, T1N2M0 }\end{array}$ & $(-)^{* 1}$ \\
\hline Horio ${ }^{15)}$ & $67 / \mathrm{M}$ & $(-)$ & UCD & mediastinum & $3 \mathrm{~cm}$ & resection & $\mathrm{HV}$ & $\begin{array}{l}\text { adenocarcinoma, } \\
\text { por, T1N0M0 }\end{array}$ & $(-)$ \\
\hline Chou16) & $56 / \mathrm{M}$ & $(-)$ & UCD & mediastinum & $1.5 \mathrm{~cm}$ & resection & $\mathrm{HV}$ & $\begin{array}{l}\text { adenocarcinoma, } \\
\text { well, T2N1M0 }\end{array}$ & $(-)$ \\
\hline Higashikuni17) & $59 / \mathrm{M}$ & $(+) ※ 2$ & $\mathrm{MCD}$ & $\begin{array}{l}\text { mediastinum } \\
\text { bone marrow }\end{array}$ & $3 \mathrm{~cm}$ & autopsy & $\mathrm{PC}$ & $\begin{array}{c}\text { giant cell } \\
\text { carcinoma, } \\
\text { TxNOM0 }\end{array}$ & $(-) ※ 1$ \\
\hline Ikari ${ }^{18)}$ & $67 / \mathrm{M}$ & $(-)$ & $\mathrm{MCD}$ & $\begin{array}{c}\text { lung } \\
\text { submaxilla }\end{array}$ & unknown & resection & Mixed & $\begin{array}{c}\text { squamous cell } \\
\text { carcinoma, } \\
\text { T1N0M0 }\end{array}$ & $(-) ※ 3$ \\
\hline Our case & $67 / \mathrm{M}$ & $(-)$ & UCD & axilla & $2.6 \mathrm{~cm}$ & resection & $\mathrm{HV}$ & $\begin{array}{c}\text { adenocarcinoma, } \\
\text { pap, TlaN0M0 }\end{array}$ & $(-)$ \\
\hline
\end{tabular}

Abbreviations:

CD: Castleman's disease, UCD: Unicentric Castleman's disease, MCD: Multicentric Castleman's disease

HV: hyaline-vascular type, PC: plasma cell type, Mixed: $\mathrm{HV}+\mathrm{PC}$

※1: cancer death, 22 : leukocytosis, anemia, and thrombocytosis

※3: death from acute pulmonary exacerbation due to interstitial pneumonia 15 months after surgery

ticentric Castleman’s disease（以下，MCD）と呼ばれる 多発症例は，PC 型と同様の症状を呈するが予後の悪さ から別のカテゴリーとして扱われることが多い. 好発部 位は胸部 $(24 \%)$, 頸部 $(20 \%)$, 腹部 $(18 \%)$ と後腹膜 (14\%) で，腋窩や鼠径部，骨盤は低頻度である5 効果を伴う単発で増大する腫瘤をみたら本疾患を念頭に 置く必要があるが, 特異的な画像所見に欠くため術前診 断は困難である。治療は外科的切除が基本となるが, 完 全切除ができなかった症例も概して予後は良好とされて
いる

一方, 腋窩リンパ節は解剖学的に上肢・肩甲部・胸壁 および乳腺からのリンパを受けるため, 肺癌の転移とし ては遠隔転移に分類される．肺から腋窩という非典型的 な転移形式を説明する仮説はいくつかあるが，実際の頻 度は $1 \%$ 未満と非常に稀である ${ }^{8-10)}$. Riquet ら ${ }^{9)}$ の報告に よると, 肺癌 1486 例における腋窩リンパ節単独転移の頻 度は，術後腋窩再発症例として 2 例 $(0.13 \%)$ に認めるの みであった. 一方で, non-squamous NSCLC（non-small 
cell lung carcinoma）の Stage IV では上頸部および腋窩 領域への転移は $12.5 \%$ に認めたという報告もある ${ }^{11)}$.つ まり, 肺癌において腋窩リンパ節に転移を認める症例は 手術による根治性は望めず, 上皮成長因子受容体チロシ ンキナーゼ阻害剤 (EGFR-TKI) や細胞障害性抗癌剤など の全身療法が施行される. よって, 腋窩リンパ節腫脹が 肺癌を起源とするものか否かを術前に診断することは, 肺癌の治療戦略を決定する上で非常に重要である.

本症例において術前に腋窩リンパ節は CNB で反応性 リンパ節腫脹と診断されたが, FDG PET/CTで SU$\mathrm{Vmax} 4.1$ と軽度高值を示し, 悪性腫瘍の可能性を否 定できなかった. FDG PET/CT において, CD 病巣は平 均 SUVmax5.8 4.1 (range 2.4-17.1) と代謝立進を示すこ とが多く, MCD や臨床症状を呈する症例は FDG 集積が 高いとされる ${ }^{12)}$. 最終的にはリンパ節切除生検により肺 癌の腋窩リンパ節転移が否定できたため, 引き続き肺原 発巣に対して定型手術が施行できた. 胸壁浸潤を伴う原 発性肺癌の中でも極限られた症例においては, 腋窩リン パ節郭清が予後改善に寄与する可能性も報告されてい $る^{13)}$ が, 本症例は胸壁非浸潤例であり, 仮に迅速診断で 腋窩結節が肺癌の転移と診断されていた場合には, 肺原 発巣は非切除となっていたと考える。

肺癌と CD の合併について, 医学中央雑誌で「肺癌, キャッスルマン病」を keyword として, 検索し得た限り 本邦で 5 例の報告 ${ }^{14-18}$ があった (Table 1). 報告例はすべ て男性で, 年齢は 37-67 歳, CD として有症状であったも のは 1 例で MCD の症例であった，診断は剖検例を除い て全て外科的切除によってなされ, 術前 $\mathrm{CD}$ と診断され た症例はなかった. 肺癌の組織型は腺癌 3 例, 巨細胞癌 1 例，扁平上皮癌 1 例であった。転帰は 2 例が癌死， 2 例は再発なし, 1 例は術後 15 力月で間質性肺炎の増悪が 原因で死亡していた。明らかな $\mathrm{CD}$ 再発症例は認めな かった.

近年 FDG PET/CT は肺癌の術前検査として広く普及 しているが, CD 病巣における SUV 值は軽度高值を示す ため, CD をリンパ節転移巣と誤認する危険性がある. 特 にCD は縦隔領域に好発するため, 肺癌をはじめとする 胸部・縦隔領域の悪性疾患の術前病期診断を困難とし, over diagnosis となる可能性がある. しかし, 積極的な切 除生検により癌性リンパ節転移を除外できた場合は, 本 症例のように原発巣に対して治癒切除が期待できる. 悪 性腫瘍に合併したリンパ節腫大においては本疾患も念頭
に入れ，積極的な切除生検を実施することが肝要と思わ れる。

\section{結語}

肺癌に同時合併した腋窩 $\mathrm{CD}$ を経験した，肺癌の腋窩 リンパ節転移との鑑別を要したが，各々の病巣における 正確な病理診断が重要であると考えられた。

\section{利益相反}

本論文について申告する利益相反はない.

\section{文献}

1. Castleman B, Iverson L, Menendez VP. Localized mediastinal lymphnode hyperplasia resembling thymoma. Cancer 1956; 9: 822-30.

2. Yoshizaki K, Matsuda T, Nishimoto N, Kuritani T, Taeho L, Aozasa K, et al. Pathogenic significance of interleukin6 (IL-6/BSF-2) in Castleman's disease. Blood 1989; 74: 1360-7.

3. Leger-Ravet MB, Peuchmaur M, Devergne O, Audouin J, Raphael M, Van Damme J, et al. Interleukin-6 gene expression in Castleman's disease. Blood 1991; 78: 2923-30.

4. Keller AR, Hochholzer L, Castleman B. Hyaline-vascular and plasma-cell types of giant lymph node hyperplasia of the mediastinum and other locations. Cancer 1972; 29: 670-83.

5. Talat N, Belgaumkar AP, Schulte KM. Surgery in Castleman's disease: a systematic review of 404 published cases. Ann Surg 2012; 255: 677-84.

6. Bowne WB, Lewis JJ, Filippa DA, Niesvizky R, Brooks $\mathrm{AD}$, Burt ME, et al. The management of unicentric and multicentric Castleman's disease: a report of 16 cases and a review of the literature. Cancer 1999; 85: 706-17.

7. Chronowski GM, Ha CS, Wilder RB, Cabanillas F, Manning J, Cox JD. Treatment of unicentric and multicentric Castleman disease and the role of radiotherapy. Cancer 2001; 92: 670-6.

8. Marcantonio DR, Libshitz HI. Axillary lymph node metastases of bronchogenic carcinoma. Cancer 1995; 76: 803-6.

9. Riquet M, Le Pimpec-Barthes F, Danel C. Axillary lymph node metastases from bronchogenic carcinoma. Ann 
Thorac Surg 1998; 66: 920-2.

10. Satoh H, Ishikawa H, Kagohashi K, Kurishima K, Sekizawa K. Axillary lymph node metastasis in lung cancer. Med Oncol 2009; 26: 147-50.

11. Lee DS, Kang JH, Lee CG, Kim SJ, Choi YJ, Lee KY, et al. Predicting Survival in Patients with Advanced Nonsquamous Non-small Cell Lung Cancer: Validating the Extent of Metastasis. Cancer Res Treat 2013; 45: 95-102.

12. Lee ES, Paeng JC, Park CM, Chang W, Lee WW, Kang $\mathrm{KW}$, et al. Metabolic characteristics of Castleman disease on 18F-FDG PET in relation to clinical implication. Clin Nucl Med 2013; 38: 339-42.

13. 渡邊法之, 岩澤 卓, 北原知洋, 柳川雄大, 宗方幸二, 高 本 香, 他. 同側腋窩リンパ節転移を伴う胸壁浸潤肺癌に 対し化学放射線療法後に根治手術を行った 1 例. 癌と化 療 2011; 38: 991-4.

14. 長尾充展, 酒井伸也, 宍戸道弘, 矢野 守, 井村真里. 肺
腺癌の術前の Thallium-201 chloride で発見されたCastleman's tumor の 1 例. 臨床放射線 1996; 41: 1041-4.

15. Horio H, Hijima T, Sakaguchi K, Kuwabara K. Mediastinal Castleman disease associated with pulmonary carcinoma, mimicking N2 stage lung cancer. Jpn J Thorac Cardiovasc Surg 2005; 53: 286-9.

16. 長 博之, 大久保憲一, 五十部潤, 上野陽一郎. 肺癌 Bulky $\mathrm{N} 2$ と鑑別を要した気管分岐部下 Castleman 病の 1 例. 日呼外会誌 2007; 21: 93-7.

17. Higashikuni Y, Mori M, Kino H. Interleukin-6-producing giant cell carcinoma of the lung with multicentric Castleman's disease-like presentation. Intern Med 2007; 46: 66973.

18. Ikari J, Kojima M, Tomita K, Nakamura T, Toyoda F, Otsuki Y, et al. A case of IgG4-related lung disease associated with multicentric Castleman's disease and lung cancer. Intern Med 2010; 49: 1287-91.

\title{
A case of lung cancer complicated by axillary Castleman's disease
}

\author{
Manabu Kakizoe ${ }^{* 1}$, Kousuke Suzuki*2 ${ }^{*}$ Noriyuki Saeki*1 \\ ${ }^{* 1}$ Department of Thoracic Surgery of Ofuna Chuo Hospital \\ ${ }^{* 2}$ Respiratory Disease Center, Showa University Northern Yokohama Hospital
}

A 67-year-old man presented to our hospital with suspected right lung cancer. Chest CT showed a 26-mm nodule with contrast enhancement at the right axilla, in addition to a 15-mm nodule in the right middle lobe of the lung. While we could diagnose the lung nodule as primary lung cancer by transbronchial lung biopsy, the axillary nodule remained undiagnosed following core needle biopsy. After an axillary specimen was diagnosed as a non-malignant neoplasm by open biopsy, the patient underwent right middle lobectomy with lymph node dissection. Pathological examination revealed the lung nodule as adenocarcinoma (pT1aN0M0) and the axillary nodule as Castleman's disease. In cases of the coexistence of lung cancer and Castleman's disease, the accurate estimation of respective lesions is essential to devise a treatment strategy for lung cancer. 